\title{
Social Integration of Vietnamese Women Married to Foreigners (Case Study in Penghu Islands and Taipei, Taiwan)
}

\author{
Le Thi Mai ${ }^{1 *}$, Bui Loan Thuy ${ }^{2}$ and Do Xuan $\mathrm{Ha}^{3}$ \\ ${ }^{1}$ Faculty of Social Sciences \& Humanities, Department of Sociology, Ton Duc Thang University, Ho Chi Minh City, Vietnam \\ ${ }^{2,3}$ Faculty of Social Sciences \& Humanities, Ton Duc Thang University, Ho Chi Minh City, Vietnam
}

\begin{abstract}
Objective - This research primarily focuses on the subject of social integration and related issues. Social integration is interpreted as being the process of inclusion and acceptance of individuals in a system, the creation of relationships among individuals and their subsequent attitudes towards society. It is the result of conscious and motivated interaction and cooperation between individuals and groups

Methodology/Technique - This paper is based on information that came from a case study undertaken in 2014 on the Penghu Islands and in Taipei, Taiwan. Quantitative data was collected from the available literature and qualitative data derived from interviews and the observation of 31 people including Vietnamese women who married Taiwanese husbands; local government officers.

Findings - Evidence from this research showed that social integration and related issues are highly influential in determining the success, or failure of cross-border marriages. The three types of social integration (formal residential, social and community and personal) overlap and complement each other to promote the social integration of Vietnamese women who married Taiwanese men.

Novelty - It is hoped that these research findings will provide a valuable resource for researchers, theorists of social integration, those interested in the impact of social capital on the lives of community members and community leaders concerned with the impact of relationships that bind the community to community.
\end{abstract}

Type of Paper: Empirical

Keywords: Social Integration; Vietnam-Taiwan; International Marriage.

JEL Classification: J12, J15.

\section{Introduction}

The process of economic globalization and international economic integration has increased the flow of capital, goods and information across borders between countries. Another important flow prompted by our increasingly globalized world and economy is that of people leaving their homeland in search of better socioeconomic opportunities. These human migration flows come in many different forms, including the focus of this paper, marriage migration.

\footnotetext{
* Paper Info: Revised: September, 2016

Accepted: January, 2017

* Corresponding author:

E-mail: lethimai@tdt.edu.vn

Affiliation: Faculty of Social Sciences \& Humanities, Department of Sociology, Ton

Duc Thang University, Vietnam
} 
The phenomenon of young rural women of the Mekong Delta Vietnam marrying foreigners, mostly from Taiwan and South Korea began in the 1990s when the 'Doi Moi' economic reforms opened Vietnam to foreign capital and subsequently, foreign influence and interaction... Eager to take advantage of Vietnam's previously untapped and rapidly expanding market economy, many Taiwanese and South Korean firms set up operations in Ho Chi Minh City, Vietnam's southern business hub. According to the Vietnam Ministry of Justice, between the period of 2005-2010, the number of Vietnamese overseas migrants as a result of international marriages was 133289 people. By 2010, the total number of Vietnamese women married to foreigners was over 80 thousand, 40 percent of whom were married to Taiwanese husbands; (Han-woo \& Cuong 2015). According to the statistics of the Department of Justice in Ho Chi Minh City, there were about 40,000 Vietnamese citizens that married foreigners during the period 2005 - 2008. Furthermore, about 92 per cent of these marriages occurred between Vietnamese females and foreign males, of the husbands 35.6 per cent were Taiwanese. (Dang, 2012).

The phenomenon of international marriage has attracted the attention of many Vietnamese and nonVietnamese scientists and the nation's media have also taken an interest. Research has generally focused on understanding the causes of this phenomenon, while the media has expressed a mostly negative interpretation, drawing attention to high divorce rates and levels of domestic abuse suffered by Vietnamese brides, including one famous case where a wife was murdered by Taiwanese husband. Such issues and the media attention afforded to them have not reversed marriage trends. Though not quite blooming as before, there is still no sign of demand abating for those Vietnamese girls who want to get married to foreigners. According to the statistics of Thot Not District, Can Tho City, up to March 10th 2014, there were 145 cases of Vietnamese women marrying foreigners, of which, 45 of those women followed their husband to live abroad.

This phenomenon has been developing over the past 30 years since the 1990s. More than two generations of these unions have settled in Taiwan. Cross-border marriage has become a feature of Vietnamese integration into the global community. Up to the end of 2009, over 100,000 cross-border marriages took place involving Vietnamese women (Bélanger \& Wang, 2012). Women entering into these marriages are often influenced by the perceived financial benefits: according to research results, about $80 \%$ of marriages between poor rural women and Taiwanese men in the Mekong Delta, Vietnam were motivated by economic considerations. These women saw their marriages as an opportunity to "change life" (Park, 2012; An, 2011; Nguyen, 2010). This raises the questions: What is the nature and prospects of a marriage founded upon money and opportunity rather than love and friendship? And what is the likelihood of and requirements for, such a marriage meeting the expectations of both partners?' These inspired us to conduct a case study in 2014 on the Penghu Islands and in Taipei, Taiwan. Our research team developed the hypothesis that "social integration issues played a definitive role in the determining whether a Vietnamese/foreign marriage could be considered successful or a failure". Research information is mainly derived from interviews conducted with Vietnamese rural women, living in the Mekong Delta who married Taiwanese males between the period of 1990-2014.

As regards characteristics of the research sites, the Penghu or Pescadores Islands are an archipelago of 64 islands and islets in the Taiwan Strait. The largest city is Magong (originally Matsu Palace in English), located on the largest island, which is also named Penghu and also includes five rural townships: Huxi Township, Baisha Township, Xiyu Township, Qimei Township and Wang-an Township. According to the Taiwan population census of Ministry of the Interior, Penghu's population was 102,304 in 2015 . The islands are characterized by small fishing ports and farm plots, the latter with earth-hugging crops such as peanuts, melons, and gourds. The majority of local men in the low class are fishermen or manual laborers with low income, unstable prospects and little education.

Taipei is the capital city. It is the political, economic, educational, and cultural center of Taiwan, and one of the major hubs of the Chinese-speaking world. Taipei City consisted of 2,686,516 people in 2013, while the metropolitan area had a population of 7,028,583. A decreasing and rapidly aging population is a looming problem for the city: by the end of 2009, one in ten people in Taipei were over 65 years of age. Foreigners 
(mainly from Indonesia, Vietnam, and the Philippines) numbered 52,426 at the end of $2008^{1}$. Up to the end of 2009, over 100,000 cross-border marriages took place involving a Vietnamese woman and a Taiwanese man. Vietnamese residents in Taiwan constitute the largest ethnic group after Han people (ethnic Chinese). (Bélanger \& Wang, 2012)

The majority of studies on marriage migration in Vietnam and Taiwan employed both qualitative and quantitative methods (Bélanger \& Wang, 2012; Graeme \& Nguyen, 2007; Xuyen, 2005). It was said that marriage migration constituted a significant vector of social change for both sending and receiving areas. The gendered aspects of this transformation generated significant interest owing to the fact that the vast majority of migrant spouses in Asia were women. The concept of 'transnationalism from below' to frame the social impact of marriage migration was often used. Researchers reviewed how the activities of marriage migrants and their families constituted either economic or social transnationalism. They then discussed how these transnational activities contributed to social change in both societies. They wanted to show the far-reaching significance of this migration flow for the region and aimed to advance understanding of marriage migration in Asia (Bélanger \& Wang, 2012).

Sociological concepts like social networks and social capital have been extensively applied to research on transnationalism (Vertovec, 2003). As an example, Vietnamese women practiced prescribed gender roles in Vietnam after their marriages to Taiwanese men. They developed different tactics in Taiwanese social contexts to fulfil their different roles in order to meet Vietnamese and Taiwanese expectations simultaneously (Tang et al., 2011). It is said that the whole phenomenon is constructed as a "social problem". Researchers adopted a social capital approach to understand the operation of ethnic food shops in Taiwan because the ability to set up a business is highly correlated with women migrants' ethnic social networks in Taiwan (Huang, 2010). However, critics noted that most migration studies focused heavily on the concepts of social capital or social networks and paid little attention to the risk embedded in the migratory process. Unequal power and class relations often were ignored in the transnational social networks and the social networks were presumed to be positive. Very few studies explore the negative side of transnational social networks that have great impact on both emigration and immigration societies (Krissman, 2005; Wang \& Bélanger, 2011). Therefore, a study combining the concepts of social networks and transnationalism in order to explore cross-border marriages should not ignore the power relationships embedded in transnational social networks. For example, the profoundly unequal power relations that exist in the transnational marriage networks organized by private marriage agencies between Vietnam and Taiwan (Wang \& Chang, 2002).

According to results of previous studies, the phenomenon of Vietnamese women (mostly rural) marrying foreigners has become increasingly popular since the 1990s. "From regions of the Mekong Delta in Vietnam's south such as Can Tho, An Giang, Dong Thap to small rural towns in the north such as Hai Phong, Quang Ninh, a growing number of young Vietnam women are marrying foreigners males, mostly from Taiwan and South Korea. According to the Consular Department of the Ministry of Foreign Affairs of Taiwan, from 1994 to 2000, the proportion of Vietnamese bride has increased rapidly: Vietnamese brides in Taiwan accounted for 10,8\% those who came from Southeast Asia in Taiwan (1994) to 26.0\% (1995); 36.7\% (1997); 52.3\% (1998); $54.8 \%$ (1999) and 2000 accounted for 61.6\% (An et al., 2005). By the end of 2010, there were over 80,000 Vietnamese women married Taiwanese men (HCM Department of Justice).

These high figures were the culmination of a variety of factors influencing people of both countries. The majority of men in Taiwan and South Korea chose Vietnamese women as their wives because they had experienced difficulty in finding Taiwanese and Korean women to marry. According to the Bureau of Statistics Ministry of Interior (MOI, 1999c), in 1998, only 50\% of single men in the age group 30-39, with low economic - social status and poor education, were able to get married to girls with similar criteria (Wang \& Chang, 2002). The majority of Vietnamese rural women marrying Taiwanese and Korean men came from poor families, yet these were not the only factors making such unions possible and desirable. The Mekong Delta is an area in which many different ethnic groups live together. Thus, the region has a tradition of multiculturalism

\footnotetext{
${ }^{1}$ Taiwan Ministry of Interior. December 2009. Retrieved 2010-07-11.
} 
and openness conducive to international marriages (An et al., 2005). However, financial motivations do appear to be the primary driving force behind mixed marriages. According to surveys undertaken in Korea and Vietnam, the main motivations for women marrying foreigners were economic: the desire to help families escape poverty and to create a better future for themselves influencing $80 \%$ of respondents (Park, 2012; Phan, 2011; Nguyen, 2010).

After 2006, the marital and intimate relationships of mixed couples were more closely examined. Wang (2007) asserts that, the Vietnamese brides have found strategies to escape the control of their husband's family: establishing close relationships with their husbands in order to relieve pressure from their mother - in - law; threatening to leave Taiwan and return to Vietnam; demanding to attend Chinese language classes in order to go out; going to the Vietnamese restaurants to meet and communicate with other Vietnamese brides; and connecting to networks of their own friends and acquaintances by mobile. Fung and Liang (2008) has written about the socialization process Vietnamese mothers impacted on their children in Taiwan and found that children were typically socialized primarily by their mothers in their father's absence. Lim (2009) found that, although Vietnamese immigrant wives were required to cook Taiwanese food for their families, they used different tactics to secretly keep the Vietnamese flavours in the cooking.

Tang \& Wang (2011) examined how immigrant women negotiate the Taiwanese patriarchal family system, and empower themselves to find ways out of domestic violence. It is said that, domestic violence arises from role conflicts between the filial daughters socialized in Vietnam and in-law's expectations of a good daughterin-law. They contend that employment status, together with Taiwan's state intervention in the Domestic Violence Prevention Act, are important to the changes in their relationships with their husbands' families. Chang \& Chang (2008) explored the Hakka dietary culture in the transnational families to understand the power relationship between the wife, husband, parents-in-law and other family members. Vietnamese immigrant spouses contribute to changing Taiwanese families and society. Elements of Vietnamese culture become embedded in Taiwanese society with the increasing number of migrant spouses present in the country.

Some Vietnamese scientists (An et al., 2005, the Vietnam Committee of Population, Family and Children in 2005) comment that there should be an objective view taken to international marriages. The existing research in Vietnam revolves around the themes of personal identity, socio-demographic characteristics of the Vietnamese brides, the reasons and motivations of their marriages and some negative consequences arising from these marriages such as marginal status, divorce, domestic violence, caring for old parents. Less examination exists on their life in their husband's homes due to limited finance curtailing the ability to conduct surveys in Taiwan (Pham \& Iwai, 2014). The existing research outlined in this section contributed greatly to the conceptualization of this study and is drawn upon throughout the article in order to illustrate, support and query our own findings.

\section{Method}

\subsection{Terminology}

Social integration is defined as the harmonious and coherent processes of the structure of a social system (Koramaz, 2014). Social integration is interpreted as the process of inclusion and acceptance of individuals in a system, the creation of relationships among individuals and their attitudes toward society. It is the result of conscious and motivated interaction and cooperation between individuals and groups (Bosswick \& Heckmann, 2006). It is suggested that social integration is composed of four basic dimensions: acculturation; placement; interaction and identification (Esser, 2000). These core components are further developed as structural integration (e.g. the acquisition of rights and the access to position and status in the core institutions of the host society); Cultural integration; Interactive integration (e.g. the acceptance and inclusion of immigrants in the primary relationships and social network of the host society) and identification integration (e.g. inclusion in a new society on the individual level. It is reflected by a feeling of belonging to the host society and identifying with it). (Bosswick \& Heckmann, 2006). Berry interpreted 
the core components of social integration by stressing multiculturalism as following: a cultural component (e.g. providing support and encouragement for cultural maintenance and development among ethnocultural groups); A social component (seeking the sharing of cultural expressions by providing opportunities for inter-group contact and the removal of barriers to full participation in society as a whole); A communication component means to promote the learning of the host nation's language (Berry, 2006: 7273).

The working definition of social integration here is the stability of relations among parts within a systemlike whole (Le, 2014). Processes of integration of Vietnamese marriage immigrants into Taiwanese society should be understood as a special case of social integration and conceptualized as: structural integration, cultural integration, interactive integration and identifiable integration (Heckmann \& Schnapper, 2003). Their social integration is developed through processes: being a trained career, going to school to obtain better education, obtaining proficiency in the Mandarin language, acceptance of norms, understanding the laws of Taiwanese society and the adoption of a common set of values within Taiwanese society; accessing social and economic resources (e.g. employment, income, socio-economic status); accessing and exercising a political voice and assuring personal security.

\subsection{Theoretical Approach}

From the theoretical perspective of social integration as quality of life, social integration is considered as the process of fostering societies that are stable, safe and just and that are based on the promotion and protection of all human rights, as well as on anti-discrimination, tolerance, respect for diversity, equality of opportunity, solidarity, security and participation of all people, including disadvantaged and vulnerable groups and persons. (Commitment 4. The Copenhagen Declaration and Programme of Action). From a capabilities perspective, the quality of life of Vietnamese brides who mostly came from poor families is dependent upon the synergistic combination of two essential ingredients: personal capacity and social opportunity. Their level of social integration is examined not only through economic and social inclusion, but also through matters of cultural citizenship, which includes issues of identity, recognition and participation from a rights-based perspective (Stone et.al., 2008; Jeannotte, 2008). These views were conceptualized and reflected within the content of indepth interviews, group discussions and fieldwork observations.

Social network analysis was used in this research to show how Vietnamese brides took advantage of relationships, experiences and opportunities to empower themselves to access social integration and achieve their goals. For example, social network analysis was used to show how Vietnamese brides access social resources and supports such as courses for learning the Chinese language and other training courses that the Taiwan government opened up for them to improve their capacity, Crucially, these endeavors also enabled Vietnamese brides to access the labor market or participate in social activities.

The sustainable livelihood approach was used in this research to analyse why the majority of rural women in South Vietnam chose marriage to foreign husbands as a strategy to escape poverty, a means to get the financial capacity of their own to support Vietnamese natal families, even as a means increase their social mobility and ascend to a higher social class. For example, the majority of Vietnamese rural women calculated the costs and benefits of their marriage migration across several countries and chose Taiwan, where they can have the greatest economic return (Borjas, 1990). It was argued, they left their natal villages to escape poverty and unemployment which acted as push factors, chose Taiwan for better employment prospects and a better and more stable life, which can be construed as pull factors (Loue \& Galea, 2007). Thus we can see that these women behaved like and were understood as rational, informed actors who moved country to achieve maximum benefit. (Todaro, 1969, 1976, 1989).

Many families in the Mekong Delta villages became wealthier owing to financial support from their daughters and Taiwanese husbands. Information related to Vietnam - Taiwan marriages disseminated quickly and had an impact on the selection partners of the other girls in the village and the surrounding villages. It was the main reason for the increase in the number of Vietnam - Taiwan marriages in a particular village in the 
Mekong Delta provinces. Both daughters in a family married Taiwan or Korean husbands. These unions were the results of connection by varied interpersonal links such as kinship, friendship, and community partnership including marriage brokers. These relationships became a kind of social capital upon which individuals can depend for their international marriages. This phenomenon has spillover effects. It conceptualizes migration as a self-sustaining diffusion process (Massey et al., 1993). It has proposed, four factors that need to be taken into account when studying immigration: "the structural forces in developing societies that promote emigration; the structural forces in developed societies that attract immigrants; the motivations, goals, and aspirations of the actors who respond to these forces by migrating internationally and the social and economic structures that arise to connect areas of out- and in-migration” (Massey, 1999).

\subsection{Data}

This research was conducted on the Penghu Islands and in Taipei, Taiwan. It was inevitable that there would be difficulties and barriers to face. These difficulties and barriers were removed step by step by our friends and colleagues. We connected with our Vietnamese graduate students studying at universities in Taipei and Penghu. As a result, we gained access to Vietnamese women who had married Taiwanese husbands. A sample survey population was compiled with the assistance of a Vietnamese woman married to Taiwanese man. She has a strong reputation amid the local community and the community of Vietnamese women residing in the Penghu Islands. Through her introduction, 31 Vietnamese women were interviewed, all of them had married Taiwanese husbands after the 1990s, settling on the Penghu Islands and in Taipei. We thought that this method was useful in the context that marrying a foreigner for economic reasons is a sensitive issue for Vietnamese women. Snowball sampling was generally conducted to reflect Vietnamese marriage immigrant's diverse social circumstances. All of them were informed of the aims of this research and their consent was obtained prior to meeting.

The research participants were very open when talking. We were able to meet them in many places such as Vietnamese food shops, parks, shopping malls and their private houses. However, there were some who did not dare to invite us to their house for various subtle reasons (e.g. they knew their husbands and family members were not pleased with our presence). Some Vietnam brides even traveled with us on their holidays. These were good opportunities for us to hear them talk, recount memories as well as the difficulties they have encountered and to observe how they behave and are treated by others in public places. We obtained their trust with our sincere attitude and respect. We regarded ourselves as respectful listeners and as participatory observers. All this helped us gather crucial and sensitive information from their narratives and behaviour. We respected their thinking and feelings. A policy of unobtrusive note taking was adopted instead of recording.

This multi-site ethnography offered insights into their relationships. It provided opportunities to look into the diverse ways in which Vietnamese wives in different locations adapt to the host country. Thus, we were able to collect rich data with a greater diversity, this helped to reconcile apparently contradictory or ambiguous accounts and identify exact information. All this contributed to reliability and accuracy of information used to interpret the findings. The information used to analyze the research contents came from in-depth interviews combined with observations. The group discussions were useful for determining the correct information and also helped to explore new findings. Although 31 Vietnamese brides selected as research informants was a small and non-representative sample, they could nonetheless tell us something about the process of Vietnamese brides' integration into the husband's family and Taiwan society.

\section{Results}

\subsection{Vietnam Marriage Immigrants Profile}

Basing on aggregation, classification and processing the information obtained through in-depth interviews and observations, the following findings were explored. 
The processes negotiated by Vietnamese women seeking Taiwanese husbands are influenced by context on both sides. During the 1990s, a popular process to facilitate these marriages was via an arrangement process termed the "Group". A woman of 38 years old told us that:

"I came here about 10 years ago by my aunt in the role of the matchmaker under the form of “Group”. The 'Group' involves: Vietnamese daughters, gathered at a location for Taiwan males viewing and selecting. She organized meetings for talking and then did procedures for their wedding including the marriage paperwork to Taiwan”.

Another woman also said her marriage took place under the "Group" and described in more detail as follows:

"Group" means a marriage broker come to one particular village, the girls from the surrounding villages give their name and registration. When enough of a certain number of trucks arrive they rent a car to take them to a hostel in the Ho Chi Minh City for the Taiwan men to look at. Once there is agreement, that matchmakers will do the procedures for their marriage after a few quick meetings with the families of that daughters. It was about from 5 to 10 couples per day, may be more... but my marriage was organized by an old friend".

However, there were also Vietnam-Taiwan marriages resulting from the connection established by women who had married Taiwanese husbands previously. After a few years living in Taiwan, a woman of 38 years old helped two other Vietnamese women meet and marry Taiwanese husbands. One of these women was a neighbor, the other, her own younger sister. She elaborated on the process:

"First, the man submitted application for marriage with foreigner wife to local authorities in the role of guarantor. Then, this application was sent to the embassy here so that they can check his marriage status and private property. Having matched the criteria, his application will be accepted and his Vietnamese wife is acceptable via Taiwan”.

It was said that this "Group" form of marriage appeared from the 1990s and it was banned in 2006 because there were so many Taiwanese males entering Vietnam many times to get married to Vietnamese wives. Conversely, there were Vietnamese women who got re-married to Taiwanese husbands after every divorce. Who are the Vietnamese women married to Taiwanese males? With regard to our sample, most of these women came from the rural villages and provinces of the Mekong Delta: Can Tho, Tra Vinh, An Giang, Soc Trang. Only 1\% came from Quang Ninh, Hai Phong City in the North of Vietnam and 1\% came from families in Ho Chi Minh City. A woman from a village in the Soc Trang province told us that:

"My village was named “Taiwan Island” because roughly 90\% its daughters married Taiwan husbands".

Meanwhile, most of the Taiwanese males settled in the countryside, seaside, on the small islands, as fishermen, farmers, unskilled labors and low income workers. Information from a group discussion reflected this:

"My husband was very honest. He and I were more 25 years apart. I did not mind much....He is too old to work anymore

"My husband was 12 years more than me. He was a driver and divorced... When I met him in Vietnam I saw he was walking with difficulty. I asked and he said that it was because he fell on the way to meet me here. Some people in this village said it was from sickness”. 
Among those who participated in our case study, in this research sample there was $1 \%$ of respondents said there are marriages based on real love and $99 \%$ of respondents indicated that their marriage was a means to escape poverty. Meanwhile, most Taiwanese men who married Vietnamese rural women faced problems in their marriage for reasons relating to their low social-economic status. It is said that standards and expectations held by Taiwanese women are very high, for example, that the man must own a car, private house and a diamond ring. As a result, many Taiwanese males, have decided to get married to Vietnamese rural women. Only 10-15 thousand dollars was enough for a marriage with a Vietnamese rural woman through marriage brokers. And these males are generally informed by marriage brokers that "the poorer the family, the more docile the girl”. However, matters these days may be changing as an interpretation by a woman from Soc Trang, 32 years old, from a group discussion in Taipei, Taiwan indicates:

"Previously the majority of women got married to Taiwan men. Men in my villages had to get married to women in other villages of Tra Vinh, Vinh Long provinces. Now, girls of 18-20 years old in my village do not marry foreigner males anymore, because their (Vietnamese males) economic status is higher with employment more stable. They get married Vietnam husbands then".

In the $1 \%$ of respondents who had marriages for real love in this research sample, spouse met each other through work, and therefore, most of them having socio-economic status, in the middle class and above. A woman from Ho Chi Minh City, 38 years old, told about her marriage as follows:

"I have lived here for 18 years. I have two sons, 16 and 17 years old. First, my husband was a fisherman. Then he enrolled a training course of apprenticed furnishing... Yes, at that time, he came to Vietnam because his company had a branch operating in Vietnam. He was in the hotel where my mother was owner. He stayed at this hotel every time going to Vietnam. My mother found him to be an excellent man. She then, asked me "do you want to get married? My husband and I are 15 years apart. And we love each other. He was handsome, gentle. When wedding, I was the second student of Ho Chi Minh University of Economics”.

Here was the story of another woman:

"He's handsome, healthy, and has stable jobs. We loved each other and got married. We had lived in Vietnam for about 3 years. During that time my son was born. He is 18 years old. We had divorced for some years. Currently we still are in the same house, still calling each other every time he goes to work in mainland China”.

And a story of another woman of 46 years old:

"My friend took him to my home and introduced us. We then got acquainted with each other, traveling, shopping and talking. He observed my family. He liked my long hair. At that time I did not know a Chinese word at all... He asked my parents: how much money do you want? My parents said that "Please, treat good to our daughter when she live in your family".

\subsection{Social integration after settlement of Vietnamese women married to Taiwan husbands}

Evidence from fieldwork and interviews suggests that the integration of Vietnamese brides in to Taiwan was reflected, first of all, in the recognition of local government of their presence from temporary residence registration, certification card to citizenship. Once granted ID, they can access the labor market and participate in other social activities that were generalized by theorists as: formal residential integration, social and community integration and personal integration. 


\subsubsection{Formal residential integration}

It was said that under the provisions of the Taiwan Government, Vietnamese wives who first arrived in Taiwan, had to apply for temporary residence registration immediately. To be granted proof of their legal presence in Taiwanese society, the Vietnamese brides completely depended on their husbands and the husband's family. This is because of two main reasons, firstly, due to the local government requirements and secondly, most of these Vietnamese women had not proficiency in Chinese in writing. The wife's application must be signed by her Taiwanese husband for his her temporary residence registration in the role of her guarantor. So, popular behaviors of Vietnamese brides in this first period involved them trying their best to satisfy the husband and the husband's family members by responding to their expectations. At the same time, depending on the support of their husband and the husband's family, and especially the determination and will of their own, Vietnamese brides often enrolled in Chinese language classes organized by local authorities to support them. A Vietnamese lady teaching in these classes explained:

"There were a few classes for Vietnam brides. They teach two languages as Vietnamese Mandarin or Mandarin - Vietnamese. Since there Vietnamese women married Taiwanese men very much. I completed that course and was granted Certification. Now I do enrichment teacher Vietnamese to children and adults here".

Information from group discussions showed that many Vietnamese women suffered from very difficult circumstances, although they had tried a lot to overcome the barriers and differences in values and expectations relating to daughter-in-laws in Taiwanese society.

“After 3 years I was granted ID,... and mine was for 4 years...All depending on my husband. I had ID but he kept it because he did not want me to go out to work. He only wanted me at home as a maid. I was at home, birthed a child, raised a baby and performed routine work. If working outside the home, I would be fined if detected by police due to not having my ID. In this context, I can only be a small trader in village markets or a maid in other houses... Generally, all of us must try to be obedient to our husband and parents in-laws so that they agreed to apply for certificate cards (ID)... With this proof, we could get a paid job and having full rights and obligations as an ordinary citizen”.

\subsubsection{Social and community integration}

The majority of Vietnamese brides are unable to communicate in Chinese. The ability to communicate in Chinese is a prerequisite for them to create relationships and access the labor market. It is very difficult for poorly educated rural Vietnamese women to write in Mandarin. It requires a great deal of effort for most Vietnamese brides to listen, understand and speak Mandarin words daily.

"Then I went to the evening classes... I studied hard. When I could talk in Chinese, though only a few words, I was able to understand exactly what my mother in law told me, and she also understands me more...From the day I was granted ID, I was assured, the spirit becomes more comfortable psychologically”.

With this proof (e.g. granted ID), Vietnamese wives can get a paid job and obtain the full rights and obligations associated with ordinary citizenship. A woman from the Vung Tau province, Vietnam, 38 years old said that:

"I paid about 3,000 Yuan yearly for insurance. If I have illness, I can make a phone call and a car will carry me to the hospital immediately. I paid only money for my son's lunch at school,... In 
addition those children in the poor family, is granted about 2,500 or 3,000 Yuan monthly. In general, women including Vietnamese ones are protected by police very well here. We participated in all activities with the Vietnamese women's community here. There is the Vietnam Women's Union in Magong City”.

A woman from Soc Trang, 32 years old, told us:

"There is a consultant room for the foreigner brides .... There are three lawyers on this island. Lawyers do a freely consultation. We always come to lawyers for advice”.

To escape from a state of dependence on their husband, Vietnamese wives practiced many different ways to earn money to help their natal family and to please their in-laws. A woman of 33 years old, working as editor in a local newspaper told us:

"The first period, I did not know anything, only went to school and relearned from grade 1 in Mandarin language. Currently I still go to school learning and also am working. I had gotten employment as editor in a newspaper for the Vietnamese community in Taiwan... Currently I do translation services. I earned a lot of money from the services related to the legal, translation,... for the Vietnamese brides. I can do what I want”.

Another Vietnamese woman suggested that we should not think all Taiwanese men are bad. She said that:

"Newspaper and mass media only issued bad news. If my Taiwanese husband was bad, I would not be the person am today. My success in job has been aided by Taiwanese. They helped me very much.... To receive the help of others, it requires their sacrifice and contribution.... I am lobbying to establish an association of Vietnamese women marrying Taiwanese. That association has not been established because of insufficient standards required by the government (e.g. must be from 35 or over people, have organized dozens of meetings...). Currently there are still many Vietnamese women do not want to join because they only focus on the economy, unaware of the benefits from the association. I am trying my best to convince them".

A woman from Hai Phong, Vietnam, 32 years old corroborated this view, suggesting:

"Taiwanese in general are very good here. At the workplace I worked with their enthusiastic support, without discrimination. If anyone performs discrimination, they can be reported to the Court and must give compensation for honor. Everyone obeys the laws of the state here ... State protects us".

\subsubsection{Personal integration}

It is said that the first years that Vietnamese women spend in Taiwan are the most turbulent, presenting difficulties for everyone. After about 5-7 years or more, the woman's ability to speak Mandarin improves, making it easier to integrate into the local life. A Vietnamese woman working at a newspaper for the Vietnamese community in Taiwan said:

"10 years ago, it was discriminated against, no cultural pluralism as now. At the time I came here, I was allowed to apply for identification papers after 3 and half years having lived here. At that time, according Taiwanese government regulations, those who want to apply for identity card, had to prove having 42 thousand Yuan in her account. It was so difficult to meet that requirement for everyone. I and colleagues in my newspaper and some associations had organized protests for this provision.... Taiwanese government recently changed the regulations, law including that 
provision. Now, just 3 and a half years, no crime at all, anyone may have citizenship. If foreign woman who had a child, wants to make citizenship she no longer necessarily needs the agreement of her husband... Before time, she must need the consent of the husband by his signature as a proof. Now we do not need that anymore, I just granted ID at the end of October, 2014. This year I will receive Taiwanese nationality”.

It was also said that there were many ways to build confidence within the husband's family. However, this is not an easy process and chiefly depends on the individual woman and her willingness to work hard, exhibit respect and gain trust. Information from group discussions conducted in Magong City, on the Penghu Islands revealed the initial difficulties associated with building these relationships. The majority of Vietnamese wives agreed that:

"In the first period, Vietnamese women met difficulties here. Taiwanese have an attitude, not welcoming to us. It was the problem that we were most unacceptable.

"I was did not suffer from that situation because I'm Chinese Vietnamese. Whereas, my Vietnamese friend was not allowed to go out to meet her friends. She was locked up in the house and doing all the work. She was expected to be obedient, dutiful to her parents in - law and her husband. She could not go to school. So she could not enter into the lives of Taiwanese society.”

The women described a variety of ways in which they could build trust between themselves and their new families. For example, a Vietnamese woman of 38 years old told us:

"People here have a habit of removing gold jewelry and putting it on the table before bedtime. At that time I was of 20, I am in truth, not greedy. I saw gold jewelry on the table while the door not closed yet many times. I gathered them to bring to my parents in law. I got their trust then.... My educational attainment and his were not the same. There were differences in thinking. At that time I was very haughty (laughs)... I always have lowered myself down to accommodate other members in the house, especially the mother-in-law. After 2 years of living with my parents in law, they died. We're living in our private house”....

A Vietnamese woman of 38 years old teaching evening classes in Penghu told us about her routine:

"During the day I work at a small industrial garment factory. I am teaching classes here to take care of Vietnamese brides and foreign ones in general. Because of knowing Mandarin, they can communicate to create relationships. Local government paid me one thousand Yuan and a half per evening class. I earned about 20 thousand Yuan monthly from working 8 hours daily in garment factory. My husband is driver of goods. We had 2 daughters. My eldest daughter is 10 years old and learning in my evening classes. Here a person can guess someone to be Taiwanese, or Vietnamese, the Philippines, Chinese, Cambodia or Indonesians ... through their communicate behaviors. Perhaps, compared to other foreigner brides coming from Southeast Asia countries, the Vietnamese brides are appreciated because of their delicate, polite communication with others. Most of them were dutiful and hardworking. They nodded to everyone they meet on the village road and made communication.

Although these women certainly share many common experiences and engage in shared practices, every Vietnamese woman has her own story, a situation of her own and her own unique way to overcome challenges. A woman from Ho Chi Minh City, 38 years old told her story as:

"Certificate of high school in Vietnam is not recognized here because its letters is not the same Chinese word system. I had to enroll in school from grades 1, learning Mandarin for 12 years... I run a "Family Mart" - a supermarket stores without my husband's support both financial and 
mentally. Now everything was stopped when one day, my son said, "if mother continues like this then it will shatter our family". I had to franchise it for my husband's sisters in law. I had no other choices. Currently I am working at convenience stores, earning 115 Yuan per hour. I had to support my son learning. When my son completes secondary school, I'll have time to enroll a training course. No training attainment, no degree, it does not do anything here. I could not forget my experiences with that store. That was my big injury, both physically and mentally. I could not forget that, although the relationship with my family did become better".

Each Vietnamese woman has her own story. One fairly common solution to overcome spiritual difficulties is, reflected by the words of a woman from Ho Chi Minh City:

"Every Sunday we come here to take a Buddhist ceremony. Since joining the worshipers, listening to Buddhist scriptures, all of us feel life is more pleasant and serene... Every woman has a situation here. We have our own sadness ... We have come to Buddhism to find salvation and serenity".

A woman of 35 years old weighs only 40kg however, every day she goes to Magong City to work by cruise from one islet She also rented a shop selling Vietnamese foods, initially selling fruit and beverages, and eventually incorporating rice, noodles. She works all day before returning home in the evening to her husband and son. Her friend informed us:

"She's very good, and knows how to sail a boat with her husband there. Poor but they are happy with 2 kids, one boy and one girl. Now she can feed her husband because he is too old to do anything anymore,... Taiwanese males appreciated Vietnamese women higher than women from other Southeast Asian countries because their virtues and hard work, they are more resigned, and good at taking care husband and children”.

It is expected that married women play simultaneously the triple roles of wife, mother, and daughter-in-law in the patriarchal Taiwanese family system. They are expected to be obedient and deferential in all family relations. These expectations parallel those that exist in Vietnamese society. As such, it is not unusual for all Vietnamese women to fulfil these responsibilities. Perhaps the main difficulty that the Vietnamese brides face is how to continue to practice their filial duties to their natal family.

So, what have Vietnamese wives done to meet both these expectations and their goals? Here was story of a woman from Tien Giang, 32 years old:

"My husband was very angry, and then so surprised when I worked, to learn Mandarin language... When he discovered that I sent money to my natal family in Vietnam, it is unacceptable for him. There was a huge argument. He also admitted later that my decision to work was correct and reasonable. I earned much money. Our Taiwanese family was becoming much better than before. He had been unemployed for months. What I demanded, he agrees with now”.

A woman who marries a man in this culture essentially marries into his family. One of first responsibilities is to learn how to serve one's in-laws. A woman may find it difficult give anything back to her Vietnamese natal family while fulfilling the duties and expectations of her new family. In this context, a newly wed woman needs to learn how to negotiate with multiple and complicated patriarchal family relations. Information obtained from interviews reflects how Vietnamese brides cope with such demands. A woman of 45 years old told us that:

"The first childbirth, it was a son. My husband and his family were very excited. There was much food to eat. They said the more I eat the more milk to rear my son. My mother in - law then advised me how to parent healthy children, especially about responsibilities of childrearing... 
while I just think about how to be able to quickly go back to work, earn money to help my natal parents building a house.... At that time, I always complained to my husband that I was tired from lack of sleep, due to my son, because of his fussy, crying ... I'm so tired already... Just a child alone, not anymore.... Hearing that, he was very sad and worried, he advised me not to do so. He asked me to produce 2-3 kids ... Finally, I persuaded him to write the application for my mother to Taiwan a few months to help me. Thus, I went back to work after a few months of leaving”.

A woman of 49 years old who comes from Can Tho told us how:

"Every time of childbirth, my mother flew to Taiwan to help me childrearing. At that time the Taiwan government did not control foreigners hardly as now. I found a work for my mother and she earned a lot of money to bring back Vietnam... I regularly send money to Vietnam. My mother was 60 years old. She had been taken my brother who suffered from paralysis since childhood. My husband is now the head of this village. He was much older than me, but he is very good. He is becoming weaker. I transport him to the hospital clinic and then return home daily. He gave me money to buy land in Vietnam”.

It was said that many Vietnamese brides are satisfied with their marriages. There are also many Vietnam Taiwan marriages that end in divorce for reasons emanating from both sides. A Vietnamese woman working as legal servicer in Taiwan told us:

"Recently 2-3 years, many Vietnamese brides were the cause of much damage. Having granted identity cards and, if they were not happy with their marriage, they were able to divorce immediately (i.e. granted identity cards means they are Taiwanese and it is easy to get a job). Most of them were employed as massage workers... for example, my friend named N, come here almost 13 years, no children, the husband's family is also ok. She bought a building in Vietnam by money of her father in - law....Two years ago, $\mathrm{N}$ obtained identity cards and divorced with her husband. She said that: "I am now Taiwanese, and then I can to do what I want". Unlike the old days, $\mathrm{N}$ had many boyfriends and girlfriends... many cases of such damage, no less".

She also remarked that most of these divorced women are better off. They feel very happy and free, their marriage had constrained them. They can now find jobs that they like and look for and build relationships with new partners in a conventional manner rather than through matchmaking arrangements and financial imperatives as before.

\section{Discussion and Conclusion}

The phenomenon of poor, Vietnamese rural women marrying Taiwanese men for primarily economic reasons boomed in the 1990s, following the implementation of the Doi Moi reforms and the emergences of their social and economic consequences. Over the past 30 years, two generations of these families have been living and working in Taiwan. The ups and downs of these marriages depended on many factors including the priority of social integration. Social integration as a whole is negotiated by processes of formal residential integration, social and community integration and personal integration. The success of integration, and ultimately the marriage, depends on a variety of factors, including the couple themselves, their families, government initiatives and support and their attitudes and accommodation of the local community. Amidst all these outside factors and processes, both spouses were required to adjust their prior behavioral standards to match their expectations and reality of their marriage. At the same time, both of them had to accept the differences of her/his partner in order to create a viable home life capable of satisfying them and building a future for their children. There were many couples who met these challenges and expressed satisfaction with 
their marriages. Conversely there were also many couples who could not resolve their issues and felt obliged to end their marriage.

This research found the cause of most conflicts to be related to divergent visions of gender roles in family and society. These visions came from culturally and socially constructed expectations of the roles a daughterin-law, wife, and mother should play in a Taiwanese family and a Vietnamese family. It was not difficult for Vietnamese brides to fulfil and match expectations from a Taiwanese family. The Vietnamese brides were educated to accept and expect similar standards since childhood. However, problems may arise when Vietnamese women attempt to balance their new duties to their husband's family with their traditional responsibilities in their natal family. Our evidences showed that first; such conflicts did not only exist in relationships, but often also incorporated the husband's family members, such as his mother, father, siblings, and other in-laws. In addition, other conflicts existed due to a change in the power relations in the family that contrasted with the traditional cultural norms of Taiwan. Vietnamese wives went out to work and earned high incomes. Their economic contribution then, was higher than that of their husband if he suffered from precarious employment status and low income. These factors caused Taiwanese husbands psychological injury, undermining their breadwinner role and damaging their Taiwanese masculinity.These conflicts not only led to negative consequences but also to opportunities for change, such as Vietnamese wives becoming more mature and autonomousThus, the introduction and integration of Vietnamese immigrant spouses has contributed to changing Taiwanese families and society. For example, the phenomenon of Vietnamese married women who have still consciously supported both their natal family and their husband's family as well (such as through their parents care, financial support for siblings or relatives who met difficulties,...) has led to some Taiwanese parents and husbands respecting both sons and daughters equally instead of the traditional privileging of male children. Economically the contribution of Vietnamese wives is also influencing power relationships between couples in the traditional Taiwanese family.

International marriages are a common phenomenon in the context of globalization. The important issue then, is the various ways in which immigrants integrate into their families and the host society for the individuals' and community's development. Evidence from this research showed that social integration and related issues are highly influential in determining the success, or failure of cross-border marriages. The three types of social integration (formal residential, social and community and personal) overlap and complement each other to promote the social integration of Vietnamese women who married Taiwanese men. The decisive role of government has also developed the implementation of current Taiwanese policies and legislation regarding immigrants.

Although this research sample was small, it could tell us something about the processes of how Vietnamese brides integrated into their husband's family and Taiwanese society. It is hoped that these research findings will provide a valuable resource for researchers, theorists of social integration, those interested in the impact of social capital on the lives of community members and community leaders concerned with the impact of relationships that bind the community to community. We also hope that the findings from the research "Social integration of Vietnamese women married foreigners - Case Study in Penghu Islands and Taipei, Taiwan" will be a useful contribution to enrich the general understanding of how women integrate into host societies. The findings of the study may also be useful for evidence-based policymakers, community development and can contribute to improving the efficiency of society management and community development.

\section{Acknowledgments}

This research is funded by the Foundation for Science and Technology Development of Ton Duc Thang University (FOSTECT), website: http://fostect.tdt.edu.vn, under Grant FOSTECT.2015.BR.21. We also appreciate and say thanks those Vietnamese women married Taiwanese men had agreed to participate in this survey. We would also like to thank the help of our graduated students and colleagues in Taiwan. Without their enthusiastic and effective cooperation, we could not carry out this study. We would like to express our sincere thanks to Dr. Dominic Hewson, an Irish colleague for English editing and proofreading of this article. 


\section{References}

Berry, J. W. (2006): Mutual Attitudes among Immigrants and Ethnocultural Groups in Canada, International Journal of Intercultural Relations, 30, 6, pp. 719-734

Borjas, G. (1990). Friends or Strangers: The Impact of Immigrants on The U.S. Economy. New York: Basis Books.

Chang, T. \& Chang, H. (2008). Dongnanya nuxing hunyin yimin yu kejia wenhua chuancheng: Yuenan yu Yinniji nuxing de yinshi pengtiao celue ("Southeast Asian Immigrant Wives and Reproduction of Hakka Dietary Culture: Vietnam and Indonesia Compared”), Taiwan Dongnanya Xuekan (Taiwan Journal of Southeast Asian Studies), 5(1):93-144.

Bélanger, D., \& Wang, H. Z. (2012). Transnationalism from below: Evidence from Vietnam-Taiwan cross-border marriages. Asian and pacific migration journal, 21(3), 291-316.

Massey, D. S., Arango, J., Hugo, G., Kouaouci, A., Pellegrino, A., \& Taylor, J. E. (1993). Theories of international migration: A review and appraisal. Population and development review, 431-466.

Massey, D. S. (1999). International migration at the dawn of the twenty-first century: The role of the state. Population and development review, 25(2), 303-322.

Koramaz, E. K. (2014). The spatial context of social integration. Social indicators research, 119(1), 49-71.

Esser, H. (2000). Soziologie. Spezielle Grundlagen. Band 2: Die Konstruktion der Gesellschaft (Sociology. Special Basics, Vol. 2: The Construction of Society), Frankfurt/New York, NY: Campus Verlag

Fung, H. and Liang, C. (2008). Yuenan mama, Taiwan Gin-a: Taiyue kuaguo hunyi jiating youer shehuihua zhi chutan ("Vietnamese Mothers, Taiwanese Children: Socializing Practices with Young Children in Sino-Vietnamese Cross-Border Marriage Families in Taipei, Taiwan”), Taiwan Renlei Xuekan (Taiwan Journal of Anthropology), 6(2):47-88.

Heckmann, F. and Schnapper, D. (eds.). (2003). The integration of immigrants in European societies, Stuttgart, Lucius and Lucius.

Hugo, G. J. (1981). Village-community ties, village norms, and ethnic and social networks: A review of evidence from the Third World. In G. F. DeJong \& R. W. Gardner (Eds.), Migration Decision Making: Multidisciplinary Approaches to Microlevel Studeis in Developed and Developing Countries (pp. 186-225). New York: Pergamon Press.

Huang, D. (2010). Taiwan yueji peiou weixing chuangye diaocha zhi tongji fenxi ("Statistical analysis on Vietnamese immigrants’ micro-business in Taiwan”). Paper presented at the 2010 Southeast Asian Studies Annual Meeting, National Tainan Arts University, Tainan, 30 April 2010.

Krissman, F. (2005). "Sin Coyote Ni Patrón: Why the 'Migrant Network’ Fails to Explain International Migration,” International Migration Review, 39(1):4-44.

Han-woo, L. \& Cuong, B. T. (2015). Việt Nam - Hàn Quốc: Một phần tư thế kỷ chia sẻ cùng phát triển Nhà xuất bản Đại học quốc gia Tp. Hồ Chí Minh (Vietnam - South Korean: A quarter of a century of shared development. Publisher of Vietnam National University, Ho Chi Minh City)

Le T.M. (2014). Social Integration of Vietnamese People Residing Abroad. International Conference Proceedings. ISBN: 978-969-9948-01-5. P. 534-577.

http://www.globalilluminators.org/wp-content/uploads/2014/09/409.pdf.

Lim, K.T. (2009). Ren liudong le, Shiwu ne? (“When People Cross the Border, How about Their Food?”). In Liuzhuan kuajie: kuaguo de Taiwan, Taiwan de kuaguo (To Cross or Not to Cross: Transnational Taiwan, Taiwan's Transnationality). Edited by Wang Hong-zen and Pei-yi Guo. Taipei: CAPAS, Academia Sinica.

Loue, S., \& Galea, S. (2007). Migration. In S. Galea (Ed.), Macrosocial determinants of population health (pp. 247-274). New York: Springer.

Nguyen, N.N.A. (2010). Current Issues of Marriage Migration in Vietnam. Paper presented the 2010 ARENA International Workshop "From Individual to Community: On Reinterpreting Citizenship \& Asian Marriage Migration” organized by Asian Regional Exchange for New Alternatives, Pusan, Korean. 4-5 June 2010.

Graeme, H., \& Nguyen, T. H. X. (2007). Marriage migration between Vietnam and Taiwan: A view from Vietnam. Watering the neighbour's garden: The growing demographic female deficit in Asia.

Park, S. H. The Cognition of Vietnamese Woman Marriage Migrants on the Economic Condition Change Before and After Marriage. Magazine of Korean Local Geographic Learning. Volume 18, No. 3. 
Phan, A., Phan, Q. T., Nguyen, Q. (2005). Hiện tượng phụ nữ Việt Nam lấy chồng Đài Loan. Thành phố Hồ Chí Minh. Nhà xuất bản Trẻ. (The phenomenon of Vietnam women married Taiwan Husband. Ho Chi Minh City. Young Publisher)

Phan, A. (2011). "Hôn nhân xuyên quốc gia: Trường hợp lấy chồng Đài Loan và Hàn Quốc ở Đồng bằng Sông Cửu Long. Tổng luận nhân văn. Viện nghiên cứu Khoa học Nhân văn. Trường Đại học nữ Seoul. Số 23. ("Transnational Marriage: Case of getting married Taiwan and South Korea Husbands in the Mekong Delta. Summa Humanities. Research Institute of Human Sciences. Seoul Women's University. No. 23).

Phan V.B. \& Iwai M. (Kanda University of International Studies). (2014). Cô dâu Việt Nam thành công ở Đài Loan: Hai nghiên cứu trường hợp. Tạp chí nghiên cứu Gia đình và giới. 1, 44-53. (Successfully Vietnam brides in Taiwan: Two case studies. Journal of Family and Gender Studies. 1, 44-53)

Populations by City and Country in Taiwan". Ministry of the Interior Population Census. https://en.wikipedia.org/wiki/Penghu.

Jeannotte, M. S. (2008, July). Promoting social integration: A breif examination of concepts and issues. In Experts Group meeting (pp. 1-15).

Stone, M., Destrempes, H., Foote, J., \& Jeannotte, M. S. (2008). Immigration and Cultural Citizenship: Responsibilities, Rights and Indicators. Immigration, Integration and Citizenship.

Tang, A. W., D. Bélanger and H. Wang. (2011). "Politics of Negotiation between Vietnamese Wives and Taiwanese Husbands.” In Politics of Difference in Taiwan. Edited by Tak-Wing Ngo and Hong-zen Wang. London and New York: Routledge.

Xuyen, T.T.K. (2005). "Nguyên nhân phụ nữ Đồng bằng Sông Cửu Long kết hôn với người Đài Loan”. Tạp chí Xã hội học, No. 1. ("The reason of Mekong Delta Women Married to Taiwan". Journal of Sociology, No. 1).

Todaro, M. P. (1969). A model of labor migration and urban unemployment in less developed countries. The American Economic Review, 59, 138-148.

Todaro, M. P. (1976). International Migration in Developing Countries. Geneva: International Labor Office.

Todaro, M. P. (1989). Economic Development in the Third World. New York: Longman.

Vertovec, S. (2003). "Migration and Other Forms of Transnationalism: Towards Conceptual Cross fertilization," International Migration Review, 37(3), 641-665.

Dang,V. (2012). Talk.Onevietnam.org, News Report. July 17, 2012.

Wang, H. Z., \& Chang, S. M. (2002). The Commodification of International Marriages: Cross-border Marriage Business in Taiwan and Viet Nam. International migration, 40(6), 93-116.

Wang, H. Z. (2007). Hidden Spaces of Resistance of the Subordinated: Case Studies from Vietnamese Female Migrant Partners in Taiwan1. International Migration Review, 41(3), 706-727.

Wang, H. Z., \& Bélanger, D. (2011). Exploitative Recruitment Processes and Working Conditions of Vietnamese Migrant Workers in Taiwan. Labour in Vietnam, ed. Anita Chan (Singapore and Canberra: Australian National University Press and ISEAS, 2011), 309-335.

Bosswick, W., \& Heckmann, F. (2006). Integration of migrants: Contribution of local and regional authorities. European Foundation for the Improvement of Living and Working Conditions. 